\title{
Al-Chizan
}

Jurnal Pemikiran Hukum Islam

ISSN 1907-0985, E ISSN 2442-8256

Vol. 13, No. 2, 2017, h. 272-293

DOI: https://doi.org/10.30603/am.v13i2.914

\section{Divorce Lawsuit Due to Polygamy in the Manado Religious Court}

\section{Edi Gunawan, Faradila Hasan}

Fakultas Syariah IAIN Manado

Email: edigunawan@iain-manado.ac.id, faradila.hasan@iain-manado.ac.id

Abstract: This article discusses the claim that the Manado City Religious Court which discussed polygamy could be the reason for filing a lawsuit for divorce and court consideration in resolving cases of divorce for polygamy in the Manado Religious Court. The research method used in this study is a descriptive qualitative presentation method with the type of field research (literature study). Polygamy can be made as an excuse for wives to ask for divorce in court. In principle, a wife may not ask for polygamy, but if someone refuses disobedience to her husband after polygamy. The consideration used by the judge in deciding divorce cases, polygamy, is in accordance with the reasons filed by the plaintiff in filing for divorce.

Keywords: Divorce, Polygamy, Manado Religious Court

\section{Cerai Gugat Akibat Poligami Di Pengadilan Agama Manado}

Abstrak: Artikel ini membahas mengenai cerai gugat yang terjadi Pengadilan Agama Kota Manado yang bertujuan untuk mengetahui mengapa poligami dapat menjadi alasan pengajuan cerai gugat dan pertimbangan hakim dalam menyelesaikan kasus cerai gugat akibat poligami di Pengadilan Agama Manado. Metode yang digunakan dalam penelitian ini adalah metode penyajian deskriptif kualitatif dengan jenis penelitian lapangan (library research). Poligami dapat dijadikan sebagai alasan bagi istri untuk mengajukan cerai gugat ke pengadilan. Pada prinsipnya seorang istri tidak boleh menuntut cerai disebabkan poligami, namun diperbolehkan jika ada kekhawatiran ketidaktaatan kepada suami setelah dipoligami.Pertimbangan yang digunakan oleh hakim dalam memutuskan perkara cerai gugat akibat poligami didasarkan pada alasan-alasan yang diajukan oleh penggugat dalam pengajuan cerai gugat.

Kata Kunci: Cerai Gugat, Poligami, Pengadilan Agama Manado 


\section{A. Pendahuluan}

Undang-Undang No.1 Tahun 1974 tentang Perkawinan (selanjutnya disebut UUP menganut azas monogami. Pasal 3 (1) dan (2) menyatakan bahwa pada dasarnya dalam suatu perkawinan seorang pria hanya boleh memiliki seorang istri saja, dan seorang wanita juga hanya boleh memiliki seorang suami. Namun pengadilan agama dapat memberikan izin kepada seorang suami untuk memiliki istri lebih dari satu orang apabila dikehendaki oleh pihak-pihak yang bersangkutan. Dalam Peraturan Pemerintah No. 9 tahun 1975 tentang Penjelasan tentang Undang-Undang Perkawinan, menyatakan bahwa apabila seorang suami ingin melakukan perkawinan lebih dari seorang, maka seorang suami harus mengajukan permohonan secara tertulis kepada Pengadilan Agama. Oleh karena itu, tidak ada alasan bagi seorang laki-laki untuk melakukan poligami di luar pengadilan.

Inpres Presiden No. 1 Tahun 1991 tentang Kompilasi Hukum Islam (selanjutnya disebut $\mathrm{KHI}$ ) telah mengatur tata cara poligami beserta syaratnya. Ada lima pasal dalam BAB IX yang mengatur tentang poligami. Ada banyak hal yang harus dipenuhi suami yang hendak berpoligami, di antaranya harus berlaku adil (baik itu tempat kediaman, giliran, dan biaya rumah tangga), mendapatkan izin dari istri pertama, tidak memiliki istri lebih dari empat orang, istri cacat atau penyakit yang tidak dapat disembuhkan, istri tidak dapat memberikan keturunan, dan istri tidak dapat menjalankan tugasnya sebagai seorang istri.

Poligami saat ini masih menjadi pembicaraan hangat di tengahtengah masyarakat. Aksi pro dan kontra terus berdatangan menyikapi permasalahan poligami termasuk di kalangan para aktivis perempuan. Terutama kalangan feminis yang menganggap bahwa poligami merupakan salah satu wadah penindasan kaum laki-laki kepada perempuan. Bahkan pandangan ini seakan-akan memperoleh legitimasi dengan adanya praktekpraktek di tengah masyarakat yang tidak sesuai dengan tuntutan Islam. pendapat yang lain menyatakan bahwa, dilarangnya poligami justru menjadi pemicu dan cenderung melegalisasi prostitusi. Berbagai pendapat terus mengalir kian semarak. ${ }^{1}$

\footnotetext{
${ }^{1}$ Syarif Zubaidah, Poligami dan Aplikasi Hukum Islam di Indonesia, dalam Tim Penulis UII, Pribumisasi Hukum Islam "Pembacaan Kontemporer Hukum Islam di Indonesia” (Cet. Ke-1; Jogjakarta: Kaukaba, 2012), 541.
} 
Edi Gunawan, Faradila Hasan

Secara keseluruhan poligami dilakukan secara sembunyi-sembunyi dan tidak tercatat di Kantor Urusan Agama (KUA). Biasanya pelaku poligami menikahi istri kedua atau ketiganya di bawah tangan dan tanpa persetujuan istri pertama. Hal ini secara langsung menimbulkan dua masalah serius; a) pelanggaran terhadap ketentuan poligami yang mengharuskan mendapatkan izin dari istri pertama melalui pengadilan, dan b) pernikahan di bawah tangan yang dapat merugikan istri. Kedua hal di atas berpotensi melahirkan permasalahan sosial. Bagi istri kedua, ia akan dihadapkan pada permasalahan legalitas anak yang dilahirkan kemudian, di mana anak akan kesulitan untuk mendapatkan statusnya seperti akte kelahiran. Padahal status akan memberikan hak bagi anak untuk mendapatkan pendidikan, kesehatan, dan lain-lain. ${ }^{2}$

Masalah poligami sekarang ini semakin dianggap sebagai perbuatan tabu, seolah-olah poligami merupakan perbuatan tercela. Hanya satu kata, tapi belakangan membuat Indonesia geger. Dari sudut pandang Islam, boleh dan tidak terlalu banyak "variabel" yang dibutuhkan untuk melakukannya. Jika kemudian masalah poligami menjadi rumit, karena banyak sekali "variabel" yang dipergunakan sebagai bahan pertimbangan. Syarat-syarat dan argumen-argumen yang kemudian muncul dikalangan umat Islam untuk "menekan" angka poligami, sebetulnya merupakan kebijakan ulama, terutama menyangkut perempuan. Meskipun masalah perempuan hanya satu, yaknimasalah perasaan yang sulit dikompromikan jika menyangkut "saingan", atau mungkin lebih tepatnya masalah eksistensi diri. ${ }^{3}$

Sebagian besar para pelaku poligami melakukan pernikahannya secara sembunyi-sembunyi atau nikah siri. Alasan yang sering dijadikan pembelaan adalah susahnya mendapatkan izin dari pengadilan agama. Padahal dalam data kementerian agama, hampir $80 \%$ pengajuan poligami dikabulkan di PA apabila syarat-syarat untuk melakukan poligami terpenuhi ${ }^{4}$. Oleh karena itu, tidak ada alasan bagi pelaku poligami untuk tidak mengajukan permohonan poligami kepada pengadilan agama apabila

${ }^{2}$ Nasaruddin Umar, Refleksi Penerapan Hukum Keluarga di Indonesia. Makalah ini disampaikan dalam acara Konsultasi Hukum Keluarga Islam di Indonesia, diselenggarakan oleh Komnas Perempuan Indonesia pada tanggal 3-4 Februari 2009 di Hotel Harris Jakarta.

${ }^{3}$ Donny Reza, http://psychoavatar.blogspot.com.2006/12/saya-dan-polemikpoligami.html. diakses pada tanggal 3 Juli 2017.

${ }^{4}$ Nasaruddin Umar, Refleksi Penerapan Hukum Keluarga di Indonesia. Makalah ini disampaikan dalam acara Konsultasi Hukum Keluarga Islam di Indonesia, diselenggarakan oleh Komnas Perempuan Indonesia pada tanggal 3-4 Februari 2009 di Hotel Harris Jakarta. 
syarat-syarat untuk berpoligami terpenuhi, karena hal tersebut telah diatur dalam UUP. Sehingga apabila ada pelaku poligami yang tidak mengajukan permohonan kepada pengadilan agama dengan alasan susahnya mendapatkan izin, maka alasan tersebut hanya merupakan pembelaan yang tidak beralasan.

Dalam UUP menganut azas monogami, yakni seorang laki-laki hanya boleh memiliki satu istri. Akan tetapi, Undang-Undang Perkawinan tidak menutup rapat-rapat poligami. Laki-laki tetap memiliki peluang untuk melakukan poligami (memiliki lebih dari satu istri) apabila syarat-syarat yang ditentukan oleh UUP terpenuhi.

Selain UUP, KHI juga mengatur tentang poligami (pasal 55-59 KHI). Beberapa syarat yang harus dipenuhi oleh seorang suami yang ingin melakukan poligami, seperti; mendapat persetujuan dari istri pertama, adanya kepastian bahwa seorang suami mampu menjamin keperluan hidup istri-istri dan anak-anak mereka, dan seorang suami harus mampu berlaku adil terhadap istri-istrinya. Syarat lain yang harus mengikut pengajuan poligami adalah bahwa istri tidak dapat menjalankan kewajibannya sebagai seorang istri, istri memiliki cacat badan atau penyakit yang tidak dapat disembuhkan, serta istri tidak dapat memberikan keturunan.

Terkait persoalan perceraian, dari tahun ke tahun selalu mengalami peningkatan. Menurut Nasaruddin Umar, ada beberapa faktor yang menjadi penyebab terjadinya perceraian, beberapa diantaranya adalah; praktek poligami suami, perselingkuhan, pemenuhan kebutuhan ekonomi, pernikahan dini, perbedaan keyakinan politik antara suami dan istri, serta masalah beda agama dalam ikatan perkawinan. Pada kasus-kasus perceraian sendiri, sebagaimana dikemukakan bahwa ada beberapa isu yang memang sangat terkait pada upaya pemenuhan keadilan bagi perempuan, yaitu mengenai pembagian harta gono gini, hak talak perempuan dalam masa gugatan perceraian, termasuk di dalamnya persoalan pemenuhan nafkah, masa iddah dan proses rujuk suami istri. ${ }^{5}$

Pada masa lalu, perceraian lebih banyak terjadi karena kehendak suami. Hal ini karena posisi suami dalam keluarga jauh lebih kuat dibandingkan isteri. Isteri lebih banyak tergantung kepada suaminya secara

${ }^{5}$ Nasaruddin Umar, Refleksi Penerapan Hukum Keluarga di Indonesia. Makalah ini disampaikan dalam acara Konsultasi Hukum Keluarga Islam di Indonesia, diselenggarakan oleh Komnas Perempuan Indonesia pada tanggal 3-4 Februari 2009 di Hotel Harris Jakarta. 
Edi Gunawan, Faradila Hasan

materi dan psikologis. Bila terjadi perceraian, maka pihaki steri dan anakanaklah yang lebih banyak merasakan dampak negatifnya.

Namun pada masa sekarang, cukup mengejutkan ketika data statistik Badan Peradilan Agama Mahkamah Agung RI menyebutkan pada tahun 2009 perkara perceraian yang diputus Pengadilan Agama/Mahkamah Syar'iyah mencapai 223.371 perkara. Perkara cerai gugat berjumlah 150.000 perkara. Ini berarti 65\% dari perkara cerai yang diproses di Pengadilan Agama di seluruh Indonesia adalah cerai gugat. ${ }^{6}$

Mengenai prosedur perceraian, pasal 39 ayat (1) UU No. 1 tahun 1974 tentang Perkawinan menyatakan bahwa perceraian hanya dapat dilakukan di depan sidang pengadilan setelah pengadilan yang bersangkutan berusaha dan tidak berhasil mendamaikan kedua belah pihak. Sehingga setiap perceraian yang dilakukan suami istri yang tidak diucapkan di depan sidang pengadilan tidak dianggap putus.

Aturan di atas berbeda dengan kitab-kitab fikih klasik yang menyatakan bahwa talak dapat terjadi dengan pernyataan dari pihak suami, baik secara lisan maupun tertulis, secara bersungguh-sungguh atau bersenda gurau. $^{7}$ Namun, hal tersebut tidak dapat diberlakukan di Indonesia karena masalah perkawinan telah diatur dalam Undang-Undang Perkawinan. Seberapa kali pun kita mengucapkan talak, tetapi hal tersebut diucapkan di luar pengadilan, maka perceraian tersebut tidak diakui oleh negara. Oleh karena itu, apabila ada suami istri yang melakukan perceraian (suami mentalak istrinya atau istri menggugat cerai suaminya) harus mengajukan ke pengadilan, sehingga pengadilan menindaklajuti pengajuan tersebut sebagai bukti keseriusan untuk melakukan perceraian.

Pada dasarnya penelitian tentang perceraian telah banyak dilakukan oleh beberapa orang dengan metode dan objek kajian penelitian yang berbeda-beda, sesuai dengan minat dan bidang ilmu masing-masing. Berikut ini peneliti akan menguraikan beberapa penelitian terdahulu dan buku yang berkaitan ataurelevandengan penelitian yang akandilakukan.

Silva Rizki Amalia, Faktor-faktor Pendorong Cerai Gugat di Pengadilan Agama Jogjakarta Tahun 2011-2013 (Tesis). Menurut penelitian ini faktor-faktor yang menjadi pendorong terjadinya cerai gugat adalah (a)

\footnotetext{
${ }^{6}$ http://badilag.net. Diakses pada tanggal 4 Juli 2017.

${ }^{7}$ M. Atho' Mudzhar, "Dampak Gender Terhadap Perkembangan Hukum Islam," Profetika: Jurnal Studi Islam, Vol. 1 No. 1, 1999, 12.
} 
nusyuz suami kepada istri, seperti suami tidak memenuhi kebutuhan ekonomi, suami melakukan KDRT, mengolok-olok dan memaki-maki istri, dan meninggalkan istri serta anak, (b) Syiqaq, yaitu terjadinya pertengkaran, percekcokan antara suami dan istri karena perselisihan, seperti masalah kesulitan ekonomi keluarga, kurangnya perhatian dan kasih sayang suami, adanya campur tangan orang ketiga, dan perselingkuhan, (c) nusyuz istri terhadap suami, seperti istri tidak taat kepada suami, tidak menjaga diri dengan baik ketika suami tidak ada di rumah, dan pergi dari rumah serta tidak melaksanakan kewajibannya, (d) suami atau istri melakukan perzinahan. Dan hubungan personal yang asimetris, tidak seimbang antara cost dan reward antara hak dan kewajiban yang memperkuat dorongan salah satu pihak untuk mengajukan perceraian.

Andi Kasmawati, Faktor Penyebab Terjadinya Perceraian di Kota Makassar (Studi Pada Kantor Pengadilan Agama Makassar). Hasil penelitian ini menunjukkan bahwa latar belakang terjadinya perceraian antara lain: (a) poligami tidak sehat, (b) krisis akhlak, (c) cemburu, (d) kawin paksa, (e) ekonomi, (f) kekejaman fisik dan mental, (g) gangguan pihak ketiga, (h) dan tidak adanya keharmonisan.

Rusmala Dewi Jayanti, Faktor-faktor Perceraian di Pengadilan Agama Palembang. Hasil penelitian ini menjelaskan bahwa faktor-faktor yang menyebabkan terjadinya perceraian antara lain; ketidakharmonisan suami istri, gangguan pihak ketiga, tidak ada tanggung jawab, ekonomi, cemburu, poligami yang tidak sehat, dan krisis akhlak.

Nurhasanah, Persepsi Perempuan Terhadap Perceraian (Studi analisis terhadap meningkatnya angka gugatan cerai di Pengadilan Agama Padang). Faktor penyebabnya adalah poligami tidak sehat, krisis akhlak, cemburu, ekonomi, tidak ada tanggungjawab, kawin di bawah umur, dihukum, cacat biologis, kekerasan dalam rumah tangga (KDRT), gangguan pihak ketiga, tidak ada keharmonisan, penganiayaan dan kekejaman mental. Sebagian wanita memiliki persepsi mengenai tingginya angka perceraian karena menganggap bahwa para wanita sudah pintar dan mandiri, mapan, dan semakin sadar untuk menyuarakan hak-hak perempuan.

Dari hasil penelitian di atas, belum ada yang melakukan penelitian secara khusus tentang poligami yang merupakan faktor yang paling tinggi mengakibatkan seorang istri mengajukan cerai gugat kepada suami. Apa lagi ketika kita melihat penelitian yang dilakukan di Pengadilan Agama Manado, 
Edi Gunawan, Faradila Hasan

berkaitan dengan poligami yang menjadi faktor penyebab diajukannya cerai gugat oleh seorang istri.

\section{B. Problematika Perceraian Akibat Poligami}

Jumlah perceraian yang kian meningkat ini memiliki beberapa penyebab. Menurut Nasaruddin Umar, dari hasil penelitian terdapat 13 faktor antara lain; ekonomi, migrasi, kekerasan dalam rumah tangga (KDRT), selingkuh, cacat, sakit, jarak, ketidakcocokan, perkawinan di bawah umur, perbedaan intelektual, dan faktor politik. ${ }^{8}$

Suatu fenomena yang menarik dari kasus perceraian di Indonesia beberapa tahun terakhir karena meningkatnya angka perceraian yang diajukan oleh istri, yakni cerai gugat. Antara $70-80 \%$ perceraian yang terjadi di Indonesia disebabkan oleh cerai gugat yang diajukan oleh istri. Hal itu bertolak belakang, di mana sebelum reformasi, sekitar $70 \%$ perceraian karena suami menalak istrinya.

Nasaruddin Umar menjelaskan bahwa, naiknya angka cerai gugat disinyalir karena semakin tingginya tingkat kesadaran hukum di kalangan perempuan. ${ }^{9}$ Hal itu dikuatkan bahwa dari rata-rata 200 ribu kasus perceraian di Indonesia pada tahun 2008 , cerai gugat mencapai $70 \%{ }^{10}$ Selain itu, masyarakat Indonesia semakin modern, terutama yang tinggal di daerah perkotaan terjadi perubahandalam struktur keluarga. Laiknya di negara-negara modern, para istri di daerah perkotaan relatif memiliki kesadaran hukum yang lebih baik, hal itu disebabkan karena tingkat pendidikan perempuan semakin tinggi.

Karena tingkat pendidikan perempuan semakin tinggi, maka kesempatan mereka untuk mendapatkan pekerjaan dan kemandirian ekonomi pun semakin besar. Dengan begitu, ketergantungan perempuan terhadap

${ }^{8}$ Kasus perceraian meningkat 10 kali lipat, Jakarta, Media Indonesia. http://www.mediaindonesia.com/read/2009/05/05/77081/92/14/kasus-perceraian-meningkat10 kali lipat. diakses pada tanggal 10 Agustus 2017.

${ }^{9}$ Kasus perceraian meningkat 10 kali lipat, Jakarta, Media Indonesia. http://www.mediaindonesia.com/read/2009/05/05/77081/92/14/kasus-perceraian-meningkat10 kali lipat. diakses pada tanggal 10 Agustus 2017.

${ }^{10}$ Kasus perceraian meningkat 10 kali lipat, Jakarta, Media Indonesia. http://www.mediaindonesia.com/read/2009/05/05/77081/92/14/kasus-perceraian-meningkat10 kali lipat. diakses pada tanggal 10 Agustus 2017. 
suami pun sudah semakin berkurang. Hal itu dapat diamati di kota-kota besar seperti Jakarta, Surabaya, Makassar, dan kota besar lainnya. Dampak dari semakin berkurannya ketergantuangan perempuan, jika suami melakukan poligami tanpa seizin istri maka istri di zaman sekarang akan menggugat suaminya dikarenakan istri merasa secara materi bisa memenuhi kebutuhannya tanpa bantuan suami.

Berikut adalah dalil-dalil yang berkaitan dengan poligami beserta penjelasannya sebagai berikut:

Dan jika kamu takut tidak dapat berlaku adil terhadap (hak-hak) perempuan yang yatim (bilamana kamu mengawininya), Maka kawinilah wanita-wanita (lain) yang kamu senangi : dua, tiga atau empat. kemudian jika kamu takut tidak akan dapat Berlaku adil. Maka (kawinilah) seorang saja, atau budak-budak yang kamu miliki, yang demikian itu adalah lebih dekat kepada tidak berbuat aniaya (QS. AnNisa' ayat 3$).{ }^{11}$

Ayat tersebut menurut Khazim Nasuha merupakan ayat yang memberikan pilihan kepada kaum laki-laki bahwa menikahi anak yatim dengan rasa takut tidak berlaku adil karena keyatimannya atau menikahi perempuan yang disenangi hingga jumlahnya empat. Akan tetapi, jika semuanya dihantui rasa takut tidak berlaku adil, lebih baik menikah dengan seorang perempuan atau hamba sahaya, karena hal itu menjauhkan diri dari berbuat aniaya. ${ }^{12}$

Dalam ayat ini Allah swt. berbicara kepada para pengasuh anak-anak perempuan yatim bahwa jika anak perempuan yatim berada di bawah pengasuhan salah seorang dari kalian, lalu apabila menikahinya dia khawatir tidak akan memberinya mahar yang setara dengan yang lazim diberikan kepada wanita-wanita lain, maka jangan menikahi anak perempuan yatim itu melainkan menikahlah dengan perempuan lain. Sesungguhnya jumlah mereka sangat banyak dan Allah tidak mempersempit peluang untuk menikah dengan mereka, melainkan dapat menikah dengan satu hingga empat wanita. Tapi jika menikahlebih dari satu wanita dia khawatir tidak

${ }^{11}$ Yayasan Penyelenggara Penterjemah Al-Qur'an disempurnakan oleh Lajnah Pentashih, Al-Qur'an dan Terjemahnya (Jakarta, CV. Darus Sunnah, 2011), 78.

${ }^{12}$ Boedi Abdullah dan Beni Ahmad Saebani, Perkawinan Perceraian Keluarga Islam(Bandung: Pustaka Setia, 2013), 34. 
Edi Gunawan, Faradila Hasan

dapat berlaku adil, maka wajib menahan diri dengan menikahi satu wanita saja. $^{13}$

Dan kamu sekali-kali tidak akan dapat berlaku adil di antara isteriisteri(mu), walaupun kamu sangat ingin berbuat demikian, karena itu janganlah kamu terlalu cenderung (kepada yang kamu cintai), sehingga kamu biarkan yang lain terkatung-katung. Dan jika kamu mengadakan perbaikan dan memelihara diri (dari kecurangan), maka sesungguhnya Allah Maha Pengampun lagi Maha Penyayang (QS. An-Nisa' ayat 129). ${ }^{14}$

Ayat tersebut menegaskan bahwa keadilan tidak mungkin dapat dicapai jika berkaitan dengan perasaan atau hati dan emosi cinta. Keadilan yang harus dicapai adalah keadilan materiel, sehingga seorang suami yang poligami harus menjamin kesejahteraan istri-istrinya dan mengatur waktu secara adil. Sayyid Sabiq mengatakan bahwa Surat An-Nisa ayat 129 isinya meniadakan kesanggupan berlaku adil kepada sesama istri, sedangkan ayat sebelumnya (An-Nisa: 3) memerintahkan berlaku adil, seolah-olah ayat tersebut bertentangan satu sama lainnya. Padahal, tidak terdapat pertentangan dengan ayat yang dimaksud. Kedua ayat tersebut menyuruh berlaku adil dalam hal pengaturan nafkah keluarga, pengaturan kebutuhan sandang, pangan, dan papan. Suami yang poligami tidak perlu memaksakan diri untuk berlaku adil dalam soal perasaan, cinta dan kasih sayang, karena semua ittu diluar kemampuan manusia. ${ }^{15}$

Dari Abdullah bin Mas'ud r.a ia berkata, 'Rasulullah saw. Bersabda kepada kami, 'hai kaum pemuda! Apabila diantara kalian mampu untuk kawin, hendaklah ia kawin, sebab kawin itu lebih kuasa untuk menjaga mata dan kemaluan. Barang siapa yang tidak mampu, hendaklah ia berpuasa, sebab puasa itu menjadi penjaga baginya'. (HR. Bukhari-Muslim)

Hadis diatas merupakanperintah kepada para pemuda untuk menikah apabila telah mampu secara biologis dan materi, karena pernikahan adalah solusi yang terbaik dari perbuatan maksiat dan perzinaan. Apabila belum

\footnotetext{
${ }^{13}$ Abu Malik Kamal bin Sayyid Salim, Fiqih Sunnah untuk Wanita, penerjemah: Asep Sobari (Jakarta: Al- I'tishom Cahaya Umat, 2007), 726.

${ }^{14}$ Yayasan Penyelenggara Penterjemah Al-Qur'an disempurnakan oleh Lajnah Pentashih, Al-Qur'an dan Terjemahnya, 80.

${ }^{15}$ Boedi Abdullah dan Beni Ahmad Saebani, Perkawinan Perceraian Keluarga Islam, 35 .
} 
mampu untuk menikah, lakukanlah puasa karena puasa dapat menjadi benteng yang menghalangi perbuatan maksiat dan nafsu birahi yang datang dari godaan setan yang terkutuk. ${ }^{16}$

Dari Ibnu Umarr.a., bahwa Ghailan bin Umayah As-Saqafi telah masuk Islam. Ketika masih jahiliah ia memiliki sepuluh istri, istriistrinya masuk Islam beserta dia, lalu dia disuruh oleh Rasulullah saw. Memilih empat istri diantara mereka (yang enam diceraikan) (HR. Imam Tirmidzi)

Rasulullah saw. Selalu membagi giliran sesama istrinya dengan adil. Dan beliau pernah berdoa, 'Ya Allah! Ini bagianku yang dapat aku kerjakan. Oleh karena itu, janganlah Engkau mencelaku tentang apa yang Engkau kuasai, sedangkan aku tidak menguasainya.' Abu Dawud berkata, 'yang dimaksud dengan Engkau kuasai, tetapi aku tidak menguasainya adalah hati (HR. Abu Dawud dari Siti Aisyah)

Hadis-hadis yang telah dikemukakan tersebut merupakan dasar hukum poligami. Beristri lebih dari seorang dilakukan oleh para sahabat dan Rasulullah saw. Bahkan Rasulullah digambarkan dalam hadis tersebut tentang tata cara mempraktikkan keadilan dalam poligami. Rasulullah membagi nafkah lahiriah keluarganya menurut kemampuannya. Sementara keadilan dalam hal "hati" beliau menyatakan tidak mempunyai kemampuan untuk menguasainya. Rasulullah hanya mampu melaksanakan keadilan dalam pemberian nafkah lahir dan batin, tetapi untuk hal cinta dan kasih sayang beliau menyatakan tidak mampu. ${ }^{17}$

Mengenai prosedur atau tata cara poligami yang resmi diatur oleh Islam memang tidak ada ketentuan secara pasti. Namun, di Indonesia telah diatur di dalam Kompilasi Hukum Islam yang dijelaskan pada pasal 56, pasal 57, pasal 58, dan pasal 59. Pada Undang-Undang Nomor 1 Tahun 1974 yang mengatur tentang poligami adalah pasal 4 dan pasal $5 .^{18}$

Penjelasan pasal 5 ayat (1) dapat dipahami bahwa suami harus meminta izin dari isteri, maka istri yang mandul pun memiliki hak prerogatif

\footnotetext{
Islam, 36.

${ }^{17}$ Boedi Abdullah dan Beni Ahmad Saebani, Perkawinan Perceraian Keluarga Islam, 38.

${ }^{18}$ Boedi Abdullah dan Beni Ahmad Saebani, Perkawinan Perceraian Keluarga Islam, 41.
}

${ }^{16}$ Boedi Abdullah dan Beni Ahmad Saebani, Perkawinan Perceraian Keluarga 
Edi Gunawan, Faradila Hasan

untuk memberi atau tidak memberi izin kepada suaminya yang bermaksud poligami. Akan tetapi, karena kondisi istri yang demikian, sangant tidak rasional atau tidak mungkin apabila istri tidak memberi izin kepada suaminya. Tentu keadaan tersebut sangat memprihatinkan bagi istri dan beralasan sangat kuat bagi suami untuk melakukan poligami.

Pemahaman terhadap pasal 4 ayat (2) (a) yang terdapat dalam Undang-Undang Nomor 1 Tahun 1974 tentang Perkawinan, posisi perempuan atau istri yang tidak dapat melahirkan keturunan ada dalam posisi dilematis, artinya terjebak dalam dua pilihan yang merugikan dan terpojok pada pelaksanaan undang-undang yang keadilannya dipertanyakan atau lebih menguntungkan pihak laki-laki atau suami.

Berdasarkan kondisi diatas, menurut Rahmat Hakim, alternatif yang dipilih oleh istri adalah sebagai berikut:

a. Bercerai secara baik-baik, walaupun praktiknya sangat dilematis. Suami atau istri tidak bertengkar, tidak bermusuhan, dan tidak bertentangan, bahkan mempunyai tujuan membina keluarga serta sama-sama mendambakan keluarga yang sakinah, mawaddah, warahmah. Disamping itu, jika perceraian alternatif yang dilakukan, akan terjadi kemudaratan baru. Kaidah hukum tidak membenarkan melakukannya, yakni mencari kemaslahatan, namun meninggalkan kemudaratan dibelakangnya. Mudaratnya bagi wanita adalah sulit mengganti suaminya karena ketidakmampuannya bertindak sebagai istri. Akan tetapi, di sisi lain jika kondisinya yang mengakibatkan istri tidak dapat menjalankan kewajibannya sebagai istri, hal itu menjadi alasan bolehnya perceraian dilakukan atas inisiatif suaminya.

b. Merelakan suaminya untuk menikah lagi, sebagai kemungkinan terakhir dan hanya satu-satunya. Tindakan ini pun dirasakan berat, terutama bagi wanita. Sulit bagi istri menerima kenyataan pahit ini, bahkan kemungkinan ini merupakan keadaan terburuk sepanjang hidupnya. Betapa tidak, suaminya akan bercumbu dengan orang lain, perbuatan yang selama ini dilakukan suami kepada dirinya. Kini hal yang sama dilakukan kepada orang lain walaupun hal itu terjadi atas izinnya. ${ }^{19}$

\footnotetext{
${ }^{19}$ Boedi Abdullah dan Beni Ahmad Saebani, Perkawinan Perceraian Keluarga Islam, 43.
} 
Mengenai masalah ini, Rasyid Ridha mengatakan, sebagaimana yang dikutip oleh Masyfuk Zuhdi yaitu, Islam memandang poligami lebih banyak membawa resiko atau madharat dari pada manfaatnya, karena manusia itu mempunyai watak cemburu, iri hati dan suka mengeluh. Watak-watak tersebut akan mudah timbul dengan kadar tinggi, jika hidup dalam kehidupan keluarga yang poligamis. Menurut Rasyid Ridho maksud dari ayat tersebut adalah untuk memberantas atau melarang tradisi jahiliyyah yang tidak manusiawi, yaitu wali anak wanita yatim mengawini anakyatim yang dipeliharanya tanpa memberi hak mahar dan hak-hak lainnya dan ia bermaksud untuk makan harta anak yatim dengan cara tidak sah, serta ia menghalangi anak yatimnya kawin dengan orang lain agar ia tetap leluasa menggunakan hartanya. Demikian pula tradisi zaman jahiliyyah yang mengawini istri banyak dengan perlakuan yang tidak adil dan tidak manusiawi hal ini dilarang oleh Islam. ${ }^{20}$

Poligami saat ini masih menjadi pembicaraan hangat di tengah-tengah masyarakat. Aksi pro dan kontra terus berdatangan menyikapi permasalahan poligami termasuk di kalangan para aktivis perempuan. Terutama kalangan feminis yang menganggap bahwa poligami merupakan salah satu wadah penindasan kaum laki-laki kepada perempuan. Bahkan pandangan ini seakan-akan memperoleh legitimasi dengan adanya praktek-praktek di tengah masyarakat yang tidak sesuai dengan tuntutan Islam. pendapat yang lain menyatakan bahwa, dilarangnya poligami justru menjadi pemicu dan cenderung melegalisasi prostitusi. Berbagai pendapat terus mengalir kian semarak. $^{21}$

Pernikahan poligami merupakan permasalahan serius dalam hukum keluarga, tidak sedikit permasalahan perceraian diakibatkan oleh poligami. Bahkan poligami menjadi salah satu penyebab terbesar terjadinya perceraian. Kebanyakan istri pertama memilih mengajukan cerai gugat karena tidak ingin dijadikan sebagai istri tua yang katanya kurang mendapat perhatian lagi dari seorang suami.

Menurut Lailatul Mardhiyah, menyebutkan bahwa kasus-kasus poligami yang kebanyakan terjadi saat ini jika ditinjau dari perspektif

\footnotetext{
${ }^{20}$ Masyfuk Zuhdi, Masail Fiqhiyah: Kapita Selekta Hukum Islam (Cet. 1; Jakarta: PT. Gria Karya, 1988), 12.

${ }^{21}$ Syarif Zubaidah, Poligami dan Aplikasi Hukum Islam di Indonesia, dalam Tim Penulis UII, Pribumisasi Hukum Islam "Pembacaan Kontemporer Hukum Islam di Indonesia” (Cet. 1; Jogjakarta: Kaukaba, 2012), 541.
} 
keadilan sangat sulit sekali. Walaupun suami tersebut mampu dalam sagi materilnya tetapi belum mampu dalam segi moril dalam pembagian terhadap istri-istrinya, sehingga masih diperlukan pemikiran lebih dalam lagi dengan pertimbangan-pertimbangan yang lebih matang dalam pengambilan keputusan. $^{22}$

Masalah poligami sekarang ini semakin dianggap sebagai perbuatan tabu, seolah-olah poligami merupakan perbuatan tercela. Hanya satu kata, tapi belakangan ini membuat Indonesia geger. Dari sudut pandang Islam, boleh dan tidak terlalu banyak variabel yang dibutuhkan untuk melakukannya. Jika kemudian masalah poligami menjadi rumit, karena banyak sekali variabel yang dipergunakan sebagai bahan pertimbangan. Syarat-syarat dan argumen-argumen yang kemudian muncul di kalangan umat Islam untuk menekan angka poligami, sebetulnya merupakan kebijakan ulama, terutama menyangkut perempuan. Meskipun masalah perempuan hanya satu, masalah perasaan yang sulit dikompromikan jika menyangkut saingan, atau mungkin lebih tepatnya, masalah eksistensi diri. ${ }^{23}$

\section{Poligami Sebagai Alasan Cerai Gugat}

Menurut hukum Islam dan undang-undang perkawinan di Indonesia, poligami memang dibolehkan tapi sebagai upaya darurat. Seorang pria yang akan melakukan poligami harus memiliki alasan yang cukup dan syaratsyarat tertentu. Menurut pasal 4 UU. No. 1 tahun 1974 seorang suami dapat mengajukan permohonan izin poligami kepada Pengadilan Agama apabila telah memenuhi syarat alternatif dan syarat komulatif. Yang termasuk syarat alternatif adalah:

1. Istri tidak dapat menjalankan kewajiban sebagai istri;

2. Istri mendapat cacat badan atau penyakit yang tidak dapat disembuhkan;

3. Istri tidak dapat melahirkan keturunan.

${ }^{22}$ http//poligami/showthread.php.html.htm.copyright2000-2009,Jelsoft,

Enterprises.Ltd.Cyber-Forums-Indonesian Cyber Community. Diakses pada tanggal 15 Maret 2016.

${ }^{23}$ Donny Reza, Saya dan Polemik Poligami http://psychorvatar.blogspot.com/ 2006/12/saya-dan-polemik-poligami.html

kalau kita merujuk pada QS. al-Nisa ayat (3), poligami memang nampak sederhana sekali. Karena bagi laki-laki cukup berlaku adil saja. Akan tetapi dalam realitanya tidaklah seindah yang dibayangkan. 
Di samping syarat alternatif di atas juga diperlukan syarat komulatif sebagaimana yang termuat dalam UUP, yaitu:

1. Adanya persetujuan istri;

2. Adanya kepastian bahwa suami mampu menjamin keperluan hidup istriistri dan anak-anak mereka.

3. Adanya jaminan bahwa suami akan berlaku adil terhadap istri-istri dan anak-anak mereka;

UU No. 1 Tahun 1974 tentang Perkawinan menjelaskan pada pasal 19 poin b mengenai salah satu alasan dalam pengajuan perceraian ke pengadilan, yakni salah satu pihak meninggalkan pihak lain selama 2 tahun berturut-turut tanpa izin pihak lain dan tanpa alasan yang sah atau karena hal lain di luar kemampuannya.

Talak diakui dalam Islam sebagai salah satu jalan keluar terakhir dari kemelut keluarga, di mana apabila hal itu tidak dilakukan, maka sebuah rumah tangga menjadi seolah-olah neraka bagi kedua belah pihak atau bagi salah satunya. Hal ini jelas bertentangan dengan tujuan dari perkawinan. Talak baru diperbolehkan apabila tidak menemukan jalan lain, karena sangat besar mudharat yang ditimbulkan, maka cara yang paling ideal dalam memecahkan kemelut rumah tangga adalah dengan jalan musyawarah dan saling mengalah.

Dalam rumah tangga sulit digambarkan tidak terjadinya sebuah percekcokan. Akan tetapi percekcokan itu sendiri beragam bentuknya, ada yang ibarat seni dan irama dalam rumah tangga dan tidak mengurangi keharmonisan, dan ada pula yang menjurus kepada kemelut yang berkepanjangan dan bisa mengancam perkawinan. Bilamana hal ini terjadi, maka salah satu di antara hal-hal di bawah ini akan terjadi:

1. Antar suami istri terdapat kesepakatan untuk tidak berpisah meskipun dua hati itu sudah berlainan arah sehingga tidak lagi merasa tenteram dalam rumah tangga mereka. Hal mungkin saja terjadi dengan berbagai pertimbangan yang sangat dewasa. Misalnya karena pertimbangan kekeluargaan, disebabkan suami istri itu dipertemukan antara kerabat dekat, atau karena sudah mempunyai keturunan yang bila terjadi perceraian akan mengakibatkan anak-anak mereka terlantar dan menderita. Untuk itu, meskipun pahit, suami istri tetap mampu menahan diri, sepakat untuk tetap berada dalam tali perkawinan, dan bergaul sebagaimana layaknya suami istri. 
2. Oleh karena berbagai pertimbangan, misalnya ada anak mereka sepakat untuk tidak berpisah, tetapi mereka berpisah rumah, adakalanya suami berpisah rumah dengan istrinya juga tidak memenuhi nafkah istrinya. Alternatif ini sering terjadi dan disaksikan dalam masyarakat. Jalan ini mereka lalui dengan berbagai motivasi. Ada yang disebabkan laki-laki beristri lagi sehingga melupakan istri pertama yang memang jika dilihat dari segi umur sudah tidak menggairahkan lagi. Di samping itu, ada pula yang semata-mata sengaja menzalimi istrinya karena dendam yang tidak bisa ia lepaskan kecuali dengan cara demikian.

3. Alternatif lain adalah memilih jalan talak. Talak berarti mengakhiri hubungan pernikahan. Dengan talak berarti masing-masing mantan istri dan mantan suami mengambil jalan hidupnya sendiri-sendiri. untuk melaksanakan perceraian itu sendiri tidak ada masalah bilamana suami istri sepakat untuk memilih alternatif ketiga ini. Yang menjadi masalah adalah bilamana yang menghendaki perceraian hanya satu pihak. Masing-masing pihak bertahan pada sikapnya. ${ }^{24}$

Alasan poligami yang mengundang perceraian sebagai berikut:

1. Istri pertama ingin memiliki suami seutuhnya, jasmani dan rohani suami hanya miliknya, apalagi jika suaminya kaya raya, pintar usaha, tampan, dan ideal. Tidak seorang pun perempuan yang boleh mengambil hati suaminya, apalagi harta bendanya.

2. Tidak terjadi komunikasi yang baik antara suami dan istri, ketika suami ingin poligami, ia memilih melakukannya secara diam-diam, selingkuh, dan banyak dibumbui dosa.

3. Suami takut jika melakukan musyawarah dengan istrinya untuk poligami, musyawarah tidak mencapai konsensus atau tidak mendapat restu.

4. Suami poligami karena melaksanakan salah satu ayat Al Qur'an yang juga dicontohkan oleh Rasulullah, tetapi bagi istri hal itu alasan yang dibuat-buat oleh suaminya agar memperoleh restu sang istri.

5. Tidak ada dalil yang menyatakan bahwa suami harus minta izin istri ketika poligami, tetapi istri tidak rela diselingkuhi dan dibohongi suami.

${ }^{24}$ Satria Effendi, Problematika Hukum Keluarga Islam Kontemporer, Analisis Yurispriuensi dengan Pendekatan Ushuliyah (Cet. ke-3; Jakarta: Kencana Prenada Media Group, 2010), 107-108. 
6. Belum ada kelaziman di bumi ini, meskipun mayoritas penduduk beragama Islam bukan berarti poligami menjadi lazim, sehingga masih dipandang tabu oleh kaum ibu.

7. Suami tidak menjalankan prinsip keadilan, istri tua sering ditelantarkan.

8. Undang-Undang Nomor $1 / 1974$ menetapkan persyaratan yang ketat bagi suami yang bermaksud poligami.

9. Umat Islam (perempuan) belum sepenuhnya mengetahui tujuan Allah membolehkan poligami, seolah-olah hanya jawaban "daripada berzina."

10. Perempuan tidak memedulikan soal adanya kebolehan poligami, yang paling menjadi masalah adalah rasa sakit hati apabila suaminya poligami. Jadi, meskipun dibolehkan oleh Islam, hati yang sakit tidak ada obatnya, dan belum ada rasa nikmat yang dialami istri ketika suaminya poligami.

11. Istri mengizinkan suaminya poligami dengan syarat perempuannya sudah tua renta, orang miskin yang memerlukan pertolongan, dan bukan untuk memuaskan hawa nafsu belaka. ${ }^{25}$

Dengan demikian, poligami bisa menjadi salah satu alasan bagi istri untuk mengajukan cerai gugat ke pengadilan agama.

\section{Pertimbangan Hakim dalam Memutuskan Perkara Cerai Gugat Akibat Poligami}

Hakim dalam memutuskan perkara pasti menggunakan pertimbangan hukum sesuai dengan perkara yang sedang diselesaikan. Sebagaicontohperkarakasus, Seorang laki-laki muslim berpoligami dengan menikahi seorang wanita sebagai istri kedua (Z), laki-laki (X) telah memenuhi syarat-syarat berpoligami dengan menjamin kehidupan kedua istrinya $(\mathrm{Y})$ dan $(\mathrm{Z})$ beserta anak-anaknya dengan menanggung biaya hidupnya secara adil, membagi waktu diantara keduanya secara adil, sehat secara fisik dan mental. Namun istri pertama (Y) selalu merasa tidak puas dan mengajukan cerai gugat kepada suaminya (X) atas dasar tidak menyetujui poligami yang dilakukan oleh suaminya.

Seorang suami yang telah melaksanakan kewajiban kepada istriistrinya secara adil, maka seorang istri dilarang untuk meminta cerai kepada

\footnotetext{
${ }^{25}$ Boedi Abdullah dan Beni Ahmad Saebani, Perkawinan Perceraian Keluarga Islam, 47.
} 
Edi Gunawan, Faradila Hasan

suaminya karena alasan poligami. Akan tetapi apabila istri pertama merasa tidak sanggup untuk menjadi istri pertama, dan ada kemungkinan akan banyak terjadi kemaksiatan yang dilakukannya, maka diperbolehkan untuk meminta cerai. Misalnya saja, apabila ia tetap menjadi istri dari suaminya yang berpoligami, maka ada kemungkinan dia akan sering membangkang terhadap suaminya. Pada prinsipnya seorang istri tidak boleh menunt ut cerai disebabkan poligami, namun diperbolehkan jika ada kekhawatiran ketidaktaatan kepada suami setelah dipoligami.

Pada perkara tersebut dapat dijelaskan pertimbangan hakim yang digunakan dalam menyelesaikan kasus cerai gugat akibat poligami.

1. Bahwa penggugat dengan tergugat telah melangsungkan pernikahan yang dicatat oleh pegawai pencatat nikah Kantor Urusan Agama sebagaimana termuat dalam kutipan Akta Nikah.

2. Bahwa pada saat menikah, penggugat sebagai perawan dan tergugat sebagai jejaka, bahwa setelah akad nikah penggugat dan tergugat tinggal serumah, kemudian berpisah.

3. Selama dalam perkawinan, penggugat dan tergugat telah melakukan hubungan badan layaknya suami istri dan telah dikarunia anak.

Penggugat memohon kepada Pengadilan Agama Manado untuk memberikan putusan sebagai berikut:

1. Mengabulkan seluruh permohonan penggugat;

2. Menghukum perceraian penggugat kepada tergugat dan menyatakan perkawinan antara keduanya putus.

3. Membebankan kepada tergugat membayar seluruh biaya perkara dan atau memberikan putusan yang seadil-adilnya atas gugatan penggugat.

4. Tergugatmemberikanjawabandi depan sidang pengadilan, bahwa rasanya suatu hal yang mustahil apabila kehidupan rumah tangganya selama bertahun-tahun tahun tidak harmonis, buktinya telah dikaruniai anak.

5. Terhadap jawaban itu, penggugat mengajukan replik bahwa perceraian mereka yang dahulu merupakan bukti ketidakharmonisan rumahtangganya. Atas replik penggugat ini tergugat tidak mengajukan duplik.

Terhadap perkara ini Pengadilan Agama Manado telah memberikan putusan sela yang isinya sebagai berikut: 
a. Menetapkan perkara ini menjadi perkara syiqaq sesuai dengan pasal 76 UU No. 3 tahun 2006 jo UU No. 50 Tahun 2009 tentang Peradilan Agama jo UU No. 50 Tahun 2009 tentang Peradilan Agama.

b. Memerintahkan kepada penggugat dan tergugat untuk menyampaikan satu orang laki-laki dan keluarga masing-masinguntuk diangkat menjadi hakam memenuhi permintaan pengadilan, penggugat dan tergugat masing-masing mengajukan seorang hakam, si A sebagai hakam dari pihak penggugat dan si B sebagai hakam dari pihak tergugat. Setelah diberi waktu 3 bulan, para hakam tersebut melaporkan tugasnya bahwa hakam dari pihak penggugat dan hakam dari pihak tergugat tidak mempunyai harapan untuk mendamaikan penggugat dan tergugat. Majelis hakim menilai bahwa para hakam tersebut tidak berhasil mengambil keputusan/kesepakatan, oleh karena itu majelis hakim menetapkan bahwa perkara ini tidak lagi menjadi perkara syiqaq dan akan diselesaikan dengan prosedur biasa. Setelah melalui tahapantahapan dan proses pemeriksaan.

Dalam perkara gugat cerai ini, pihak majelis hakim pengadilan agama telah berupaya mengambil langkah-langkah positif dengan kelangsungan hubungan suami-istri tersebut. Masalahnya langsung atau tidak langsung adalah menyangkut masa depan anak-anak. Untuk itu, langkah pertama yang diambil oleh pengadilan agama ialah upaya perdamaian, dan setelah upaya itu tidak berhasil baru dilakukan penyelesaian.

Perdamaian lewat hakam, Pengadilan Agama sebelum memberi keputusan telah berupaya mendamaikan mereka dengan menunjuk dua orang untuk menjadi hakam. Langkah ini sesuai dengan ayat al-qur'an surah annisaayat 35 yang artinya: "Dan jika kamu khawatirkan ada persengketaan antara keduanya, maka kirimlah seorang hakam dari keluarga laki-laki dan seorang hakam dari keluarga perempuan. Jika kedua orang hakam tersebut bermaksud mengadakan perbaikan, niscaya Allah memberi taufiq kepada suami-istri itu. Sesungguhnya Allah Maha Mengetahui lagi Maha Mengenal”.

Berhubungan dengan kasus yang dibahas ini, maka dua orang hakam yang dipilih untuk menyelesaikan sengketa secara kekeluargaan ternyata tidak berhasil mendamaikan mereka. Dalam salah satu pertimbangannya majelis hakim pengadilan agama menyatakan: "Menimbang, bahwa perkara tersebut ditetapkan menjadi perkara syiqaq dan mengangkat hakam dari 
Edi Gunawan, Faradila Hasan

masing-masing pihak yaitu: (1) Si A, sebagai hakam dari pihak penggugat, dan (2) si B, sebagai hakam dari pihak tergugat. Menimbang, bahwa ternyata setelah kurang lebih tiga bulan diberi kesempatan kepada hakam penggugat dan terguga tuntuk melaksanakan tugasnya maka melaporkan hasilnya secara tertulis pada pokoknya sebagai berikut:

1. Hakam penggugat dan tergugat tidak ada harapan untuk mendamaikan dan adanya kata sepakat untuk cerai antara penggugat dan tergugat.

2. Hakam penggugat menyatakan mengundurkan diri dari jabatan hakam dan menyerahkan segala urusannya kepada pihak penggugat.

3. Hakam tergugat melaporkan bahwa antara penggugat dan tegugat sudah bisa rukun kembali, maka dengan demikian tugasnya sudah selesai. Menimbang, bahwa tugas hakam tersebut tidak berhasil, maka majelis hakim menetapkan bahwa perkara ini diselesaikan dengan prosedur biasa.

4. Penyelesaian dengan prosedur biasa untuk menyelesaikan perkara ini, dalam salah satu pertimbangan pengadilan agama dikatakan: Menimbang, bahwa dari pertimbangan-pertimbangan tersebut di atas telah terjadi hal-hal sebagai berikut:

a. Telah terjadi perselisihan dan pertengkaran terus-menerus antara penggugat dengan tergugat yang tidak bisa didamaikan lagi sebagaimana yang dimaksud dalam pasal 19 huruf f PP No 9 Tahun 1975.

b. Pihak penggugat sangat tertekan dan terluka hatinya dan telah menjadi trauma akibat tergugat kawin lagi dengan wanita lain, demikian juga sudah tidak ada mawaddah dan rahmah.

c. Antara penggugat dan tergugat ada perbedaan sifat dan kepribadian sehingga sulit untuk hidup harmonis lagi dalam rumah tangga.

d. Apabila rumah tangga/perkawinan dipertahankan dikhawatirkan akan menimbulkan mudarat yang lebih besar atau penderitaan yang berkepanjangan.

e. Berdasarkan hal-hal tersebut di atas, maka sudah seharusnya gugatan penggugat harus dikabulkan.

Majelis hakim juga mengemukakan pendapat ulama yang pada pokoknya membenarkan adanya perceraian bilamana hubungan suami istri telah hampa sebab meneruskan perkawinan berarti menghukum salah satu 
pihak dengan penjara yang berkepanjangan. Hal itu dinilai oleh ulama sebagai aniaya yang bertentangan dengan keadilan.

Dalam menyelesaikan sengketa perceraian, maka yang diperlukan dalam bertahkim adalah kebijaksanaan para hakam dan adanya sifat mau mengalah dari kedua belah pihak yang sedang bersengketa. Untuk mewujudkan tujuan perdamain melalui tahkim, dalam pelaksanaannya sangat tergantung pada kemahiran seorang hakam dalam menyentuh hati masing-masing yang bersengketa, sehingga keduanya tetap berada dalam iktikad baik sebagai dua orang suami istri yang sudah mempunyai tanggung jawab yang banyak. Meskipun harus menegaskan mana pihak yang benar dan mana pihak yang salah, namun pihak yang dinyatakan salah hendaklah secara rela hati mengakui kekeliruannya. Dengan demikian tujuan penyelesaian sengketa keluarga secara kekeluargaan dapat tercapai.

Pengadilan Agama dalam memutus perkara cerai gugat akibat poligami telah sesuai dengan prosedur penyelesaian perkara perceraian. Berdasarkan alasan-alasan pokok yang diajukan oleh penggugat sebagai pertimbangan hakim dalam memutus yang disertai dengan alat bukti dan saksi yang telah memenuhi syarat dan menguatkan gugatannya. Majelis hakim telah melihat bahwa antara penggugat dan tergugat tidak ada harapan untuk hidup rukun kembali

\section{E. Penutup}

Poligami dapat dijadikan sebagai alasan bagi istri untuk mengajukan cerai gugat ke pengadilan. Pada prinsipnya seorang istri tidak boleh menuntut cerai disebabkan poligami, namun diperbolehkan jika ada kekhawatiran ketidaktaatan kepada suami setelah dipoligami. Apabila istri pertama merasa tidak sanggup untuk menjadi istri pertama, dan ada kemungkinan akan banyak terjadi kemaksiatan yang dilakukannya, maka diperbolehkan untuk meminta cerai. Apabila ia tetap menjadi istri dari suaminya yang berpoligami, maka ada kemungkinan dia akan sering membangkang terhadap suaminya. Begitu juga dalam pasal 19 huruf $b$ dapat dijadikan alasan untuk mengajukan cerai gugat bahwa suami telah meninggalkan istri selama 2 tahun berturut-turut atau dengan alasan yang lain.

Pertimbangan yang digunakan oleh hakim dalam memutuskan perkara cerai gugat akibat poligami didasarkan pada alasan-alasan yang 
Edi Gunawan, Faradila Hasan

diajukan oleh penggugat dalam pengajuan cerai gugat. Dalam memutuskan perkara cerai gugat akibat poligami, berdasarkan pada perundanganundangan yang berlaku di Indonesai, yaitu UU No.1 Tahun 1974 tentang Perkawinan, Peraturan Pemerintah No.9 Tahun 1975 tentang Pelaksanaan UU No. 1 Tahun 1974 tentang Perkawinan dan Inpres Nomor 1 Tahn 1991 tentang Kompilasi Hukum Islam serta berdasarkan penilaian hakim selama persidangan.

\section{DAFTAR PUSTAKA}

Abdullah, Boedi dan Saebani, Beni Ahmad. Perkawinan Perceraian Keluarga Islam, Bandung: Pustaka Setia, 2013.

Efendi, Satria. Problematika Hukum Keluarga Islam Kontemporer, Analisis Yurispriuensi dengan Pendekatan Ushuliyah, Cet. ke-3; Jakarta: Kencana Prenada Media Group, 2010.

Mudzhar, M. Atho'. Dampak Gender Terhadap Perkembangan Hukum Islam, Profetika, Jurnal Studi Islam, Vol. 1 No. 1, 1999.

Salim, Abu Malik Kamal bin Sayyid, (2007),Fiqih Sunnah untuk Wanita, penerjemah: Asep Sobari, Jakarta: Al- I’tishom Cahaya Umat.

Umar, Nasaruddin. Refleksi Penerapan Hukum Keluarga di Indonesia.Makalah ini disampaikan dalam acara Konsultasi Hukum Keluarga Islam di Indonesia, diselenggarakan oleh Komnas Perempuan Indonesia pada tanggal 3-4 Februari 2009 di Hotel Harris Jakarta, 2009.

Yayasan Penyelenggara Penterjemah Al-Qur'an disempurnakan oleh Lajnah Pentashih. Al-Qur'an dan Terjemahnya, Jakarta, CV. Darus Sunnah, 2011.

Zubaidah, Syarif. Poligami dan Aplikasi Hukum Islam di Indonesia, dalam

Tim Penulis UII,Pribumisasi Hukum Islam "Pembacaan Kontemporer Hukum Islam di Indonesia”, Cet. Ke-1; Jogjakarta: Kaukaba, 2012.

Zubaidah, Syarif. Poligami dan Aplikasi Hukum Islam di Indonesia, dalam Tim Penulis UII, Pribumisasi Hukum Islam "Pembacaan 
Cerai Gugat Akibat Poligami di Pengadilan Agama Manado

Kontemporer Hukum Islam di Indonesia" Cet. Ke-1; Jogjakarta: Kaukaba, 2012.

Zuhdi, Masyfuk. Masail Fiqhiyah: Kapita Selekta Hukum Islam, Cet-1; Jakarta: PT. Gria Karya, 1988.

http//poligami/showthread.php.html.htm.copyright2000-2009,Jelsoft,

Enterprises.Ltd.Cyber-Forums-Indonesian Cyber Community.

Diakses pada tanggal 2 Juli 2017.

http//poligami/showthread.php.html.htm.copyright2000-2009,Jelsoft,

Enterprises.Ltd.Cyber-Forums-Indonesian Cyber Community.

Diakses pada tanggal 15 Maret 2016.

http://badilag.net. Diakses pada tanggal 4 Juli 2017.

http://www.mediaindonesia.com/read/2009/05/05/77081/92/14/kasus-

perceraian-meningkat-10kali lipat. diakses pada tanggal 10 Agustus 2017. 